\title{
EVAPORATION OF SNOW AND ICE IN SCHARFFENBERGBOTNEN, DRONNING MAUD LAND, ANTARCTICA
}

\section{(Abstract)}

\author{
by
}

Stig Jonsson and Per Holmlund

(Department of Physical Geography, University of Stockholm, S-106 91 Stockholm, Sweden)

Scharffenbergbotnen is a $3 \times 6 \mathrm{~km}$ large basin of interior ice drainage on the north-western side of Heimefrontfjella in Dronning Maud Land, Antarctica. The elevation at the bottom of the depression is $1142 \mathrm{~m}$ a.s.1., while bedrock immediately to the south-east of this point rises to more than $2750 \mathrm{~m}$. Ice enters the basin mainly from a low ice divide $(1250 \mathrm{~m}$ a.s.l.) in the west but also through a $400 \mathrm{~m}$ high icefall in the east. Two separate blue-ice areas constitute approximately half the surface of the basin, while the other half is snow-covered.

As part of SWEDARP (Swedish Antarctic Research Programme) 1988 a research project to study the origin and mass balance of this basin has been initiated. A net of 28 stakes has been established for studies of ablation and ice movement (Fig. 1). The ice thickness was measured by radio-echo sounding (Fig. 2) and particular care was devoted to get the correct ice depths at the entrance to the basin. The ice thickness along a central section of the basin varied from $1000 \mathrm{~m}$ in the west to $400 \mathrm{~m}$ at the bottom of the depression.

In order to explain the ablation two automatic weather stations (Aanderaa 2700) were operated during the field season (mid-January to mid-February 1988). One was placed in the bottom of the depression, the other $13 \mathrm{~km}$ to the west in an area where a small net accumulation took place during the field season. The latter station should record "normal" weather. Sensors registering wind speed, wind gust, wind direction, incoming solar radiation, air temperature and relative humidity were installed at both weather stations, while reflected solar radiation, net radiation and air pressure were measured only at Scharffenbergbotnen. All sensors except the air pressure sensor were placed $270 \mathrm{~cm}$ above the ground, and all were read every 10 minutes.

Ablation measurements were carried out between 16 January and 18 February on 24 of the stakes. 12 of these stakes were standing in snow. All but one recorded ablation and, as no signs of melting could be seen, all ablation must be due to evaporation and perhaps for the snowy areas some wind erosion. The average ablation rate for the whole field season was $0.7 \mathrm{~mm}$ w.eq. per day with a standard deviation of 0.3 . Stakes in blue ice showed slightly higher values than those in snow. For January, when air temperatures always were above $-10^{\circ} \mathrm{C}$, the average ablation rate was $1.2 \mathrm{~mm}$ w.eq. per day.

A regional difference in ablation rate across the depression was also measurable. Maximum ablation took place immediately below the arête forming the north-eastern boundary of the basin and diminished towards south-west. Below the arête the ablation rate was above $1 \mathrm{~mm}$ w.eq. per day for the whole field season and more than $2 \mathrm{~mm}$ w.eq. per day during January.

A comparison of weather data between the two stations showed the following main differences. In the depression the temperature showed no daily variation and relative humidity varied between 40 and $60 \%$. The weather at the other station was characterised by colder nights and weaker winds as well as by a relative humidity between 60 and $80 \%$. The reason for the regional variation in ablation can be explained by almost constant easterly winds during January and the drop in altitude (between 300 and $500 \mathrm{~m}$ ) along the north-western arête.

On 11 February 1988 the weather station at Scharffenbergbotnen was converted into a system for satellite (Argos) transmission of weather data to Europe. The transmission seems to have been successful but the data are not yet processed. At present (January 1989) one of us is remeasuring the stakes (ablation and ice movement) during SWEDARP 1989. Preliminary results sent by radio point towards a yearly net ablation rate of $120 \mathrm{~mm}$ w.eq. for the blue-ice area in the bottom of the depression. $25 \%$ of the ablation took place during the field season 1988 , but $75 \%$ has evaporated between 18 February 1988 and mid-January 1989. Probably most of the evaporation took place during December 1988 and January 1989, which means a very high daily evaporation rate $(2.5 \mathrm{~mm}$ w.eq. per day). 